\title{
Physical attributes and organic matter in soils with different use/management cultivated with the main crops in the Cerrado of western Bahia, Brazil
}

\section{Atributos físicos e matéria orgânica em solos com diferentes uso/manejo cultivados com as principais culturas nos cerrados da região oeste da Bahia, Brasil}

\author{
Heliab Bomfim NUNES ${ }^{1}$; Joaquim Pedro SOARES NETO²; Vandayse Abades ROSA ${ }^{3}$; \\ Aline dos Santos de CARVALHO \\ ${ }^{1}$ D.Sc. em Manejo de Solo, Universidade do Estado da Bahia (UNEB), hbnunes@uneb.br \\ ${ }^{2}$ Autor para correspondência, - D.Sc. em Geotecnia, professor da Universidade do Estado da Bahia, Barreiras, BA, \\ jpsneto@uneb.br \\ ${ }^{3}$ Engenheira Agrônoma, Técnica da Pecuária Oeste, deyseabades@hotmail.com \\ ${ }^{4}$ Engenheira Agrônoma, Mestranda em Agronomia pela Universidade Federal de Goiás, aline.tsc.carvalho@gmail.com
}

Recebido em: 30-07-2020; Aceito em: 26-10-2020

\begin{abstract}
Given the importance of agriculture in western Bahia and the conserving natural resources, this study evaluates soil aggregation, soil organic matter, and soil density in the most important crops in that region. Seventeen areas with different management were sampled: five areas cultivated with soybean (Glycine max L.), two cultivated with maize (Zea mays L.), two cultivated with cotton (Gossypium hirsutum L.), two cultivated with eucalyptus (Eucalyptus spp.), four with pasture, one with crop-livestock integration, two cultivated with coffee (Coffea arabica L.), and two areas of preserved Cerrado. Cotton cultivation was the one that most affected soil aggregation, even under no-tillage. For soybean, no-tillage improved soil aggregation in comparison to conventional tillage. Soil density increased significantly in cultivated areas in comparison to areas in equilibrium. The no-tillage system proved to be efficient in maintaining soil organic matter in soybean growing areas.
\end{abstract}

Additional keywords: carbon; no-tillage; soil aggregates; soil conservation; soybean.

\section{Resumo}

Dada a importância da agricultura na Região Oeste da Bahia e da conservação dos recursos naturais, objetivou-se avaliar a agregação, matéria orgânica e densidade do solo nas culturas de maior expressão nessa Região. Foram amostradas 17 áreas com diferentes manejos, sendo cinco áreas cultivadas com soja (Glycine max L.), duas cultivadas com milho (Zea mays L.), duas cultivadas com algodão (Gossypium hirsutum L.), duas cultivadas com eucalipto (Eucalyptus spp.), quatro com pasto, uma com integração lavoura pecuária, duas cultivadas com café (Coffea arabica L.) e duas áreas de cerrado preservado. $O$ cultivo do algodoeiro foi o que mais impactou a agregação do solo, mesmo em sistema plantio direto. O cultivo da soja em sistema plantio direto proporcionou maior agregação quando comparado com o plantio convencional. A densidade do solo aumentou significativamente nas áreas cultivadas quando comparadas com as áreas em equilíbrio. O sistema plantio direto se mostrou eficiente em manter a matéria orgânica do solo nas áreas cultivadas com soja.

Palavras-chave adicionais: agregados do solo; carbono; conservação do solo; plantio direto; soja.

\section{Introduction}

Western Bahia stands out nationally as an agricultural hub. Among the crops with higher economic value, total area, and planted area are soybean (Glycine max L.), cotton (Gossypium hirsutum L.), maize (Zea mays L.), eucalyptus (Eucalyptus spp.), coffee (Coffea arabica L.), and pastures. Of these, soybean occupies the largest area, with 1.6 million hectares in the 2017/2018 harvest (AIBA, 2018).

This region shows a predominance of sandy soils with peculiar characteristics that must be considered for proper management aiming at greater longevity, stability, and safety in production (Donagemma et al., 2016). In view of the fragility of these soils, it is important to assess their quality using conservation indicators (Obade \& Lal, 2016). Aggregation, density, and organic matter are sensitive indicators that are practical in assessing the impact of crops and cultivation systems on soil quality.

Practices that preserve soil aggregation are fundamental for the functioning and balance of the production system (Bronick \& Lal, 2005). Soil density and organic matter content are also essential to achieve an economically and environmentally viable production (Hamza \& Anderson, 2005; Shi \& Schulin, 2018).

Poor management of agricultural soils can alter their physical and chemical attributes, increasing 
soil density and/or degrading organic matter. Hamza \& Anderson (2005) pointed out that soil compaction in agricultural ecosystems is due either to machinery traffic in the various cultural treatments or to animal trampling. The authors also highlight that the quantity and quality of organic matter is an important factor in soil compaction.

Given the relevance of the crops listed above and the importance of maintaining soil physical and chemical properties, this study evaluates soil density, aggregation, and organic matter in the most important crops in western Bahia, Brazil.

\section{Material and methods}

Characterization of the study site and soil use/management

The soils were sampled from farms in western Bahia, at the 0-0.20 m layer, with four replications. This layer was selected for sampling because it is the area of greatest influence of cultural treatments, thus with a greater probability of occurring changes due to use/management. Seventeen areas were sampled having different uses and managements, with native Cerrado (NC) as a reference, as shown in Table 1.

Table 1 - Soil uses and managements.

\begin{tabular}{|c|c|}
\hline Area/code & Use/management \\
\hline NC & Native Cerrado \\
\hline DPS (S) & Direct seeding with soybean monoculture in the last eight years \\
\hline DPS (S/M) & Direct seeding with soybean-maize rotation in the last five years \\
\hline CPS $(\mathrm{S} / \mathrm{M} / \mathrm{C})$ & Conventional system with soybean-maize-cotton rotation in the last five years \\
\hline CPS (S/M) & Conventional system with soybean-maize rotation in the last five years \\
\hline CPS (S3/M2) & Conventional system with soybean for three years and maize in the last two years \\
\hline CPS (M/S) & Conventional system with maize-soybean rotation in the last five years \\
\hline DPS (C5) & Direct seeding with cotton monoculture in the last five years \\
\hline E3 & Eucalyptus with three years of implantation, after removal from the Cerrado \\
\hline E5 & Eucalyptus with five years of implantation, after removal from the Cerrado \\
\hline $\mathrm{P} 1 \mathrm{Bb}$ & $\begin{array}{l}\text { Pasture of Brachiaria brizantha cv. Marandu implanted one year after removal from the } \\
\text { Cerrado, with acidity correction and phosphate fertilization }\end{array}$ \\
\hline P5Bb & $\begin{array}{l}\text { Pasture of Brachiaria brizantha cv. Marandu implanted five years after removal from the } \\
\text { Cerrado, with acidity correction and phosphate fertilization }\end{array}$ \\
\hline $\mathrm{P} 15 \mathrm{Bb}$ & $\begin{array}{l}\text { Pasture of Brachiaria brizantha cv. Marandu implanted } 15 \text { years ago and renovated } 1 \text { year ago } \\
\text { with acidity correction and phosphate fertilization }\end{array}$ \\
\hline P5Ag & $\begin{array}{l}\text { Pasture of Andropogon gayanus implanted five years ago, with acidity correction and without } \\
\text { phosphate fertilization }\end{array}$ \\
\hline ILP & $\begin{array}{l}\text { Soybean-maize rotation for three years and pasture of Brachiaria brizantha cv. Marandu in the } \\
\text { last two years }\end{array}$ \\
\hline Cof 3 & $\begin{array}{l}\text { Three-year-old coffee implanted after removal from the Cerrado, with soil acidity correction and } \\
\text { recommended fertilization for the crop }\end{array}$ \\
\hline Cof 20 & $\begin{array}{l}\text { Twenty-year-old coffee implanted after removal from the Cerrado, with soil acidity correction } \\
\text { and recommended fertilization for the crop }\end{array}$ \\
\hline
\end{tabular}

The soil of the area under no-tillage with grain crops was classified as a dystrophic Red-Yellow Latosol, and the soil of eucalyptus plots was classified as an orthic Quartzarenic Neosol, both in flat relief. The results of the chemical analysis are shown in Table 2.

According to the Köppen classification, the climate of the study area is type Aw (tropical rainy), with a rainy season from October to April and a dry season from May to September.

\section{Soil sampling}

The samples with preserved structure were collected using a volumetric ring (Kemper \& Rosenau,
1986) with a capacity of $1000 \mathrm{~cm}^{3}(12.74 \mathrm{~cm}$ in height and $10 \mathrm{~cm}$ in diameter). For this purpose, the soil was moistened and, after the water was drained, the cylinders were placed to remove samples in the form of monoliths. Then, the cylinders were removed by digging around them and cutting the soil just below them. After removal, the cylinders were wrapped in plastic film, packed in plastic buckets, and taken to the Soil Physics Laboratory of the State University of Bahia for processing the samples. In the laboratory, the soil was removed from the cylinders, being then ground while considering fragile points and allowed to air dry for fortyeight hours. 
Table 2 - Result of chemical analyzes of soils in the studied areas according to described in table 1, in the Western Region of Bahia, Brazil.

\begin{tabular}{lccccrr}
\hline Area & $\mathrm{pH}\left(\mathrm{H}_{2} \mathrm{O}\right)$ & $\mathrm{Al}^{3+}$ & $\mathrm{Ca}^{2+}+\mathrm{Mg}^{2+}$ & $\mathrm{Ca}^{2+}$ & \multicolumn{2}{c}{$\mathrm{P}$} \\
\cline { 3 - 6 } & & $----------\left(\mathrm{cmol}_{\mathrm{c}} \mathrm{dm}^{-3}\right)$ & $----\mathrm{K}^{+}$ \\
\hline NC & 4.67 & 1.10 & 0.79 & 0.25 & 2.00 & 60.47 \\
DPS (S) & 5.60 & 0.00 & 3.30 & 2.39 & 72.31 & 70.54 \\
DPS (S/M) & 4.91 & 0.20 & 2.96 & 2.11 & 53.95 & 70.54 \\
CPS (S/M/C) & 6.65 & 0.00 & 3.21 & 2.30 & 16.20 & 80.62 \\
CPS (S/M) & 5.65 & 0.00 & 1.99 & 1.38 & 74.12 & 60.47 \\
CPS (S3/M2) & 4.55 & 0.40 & 1.92 & 1.34 & 51.30 & 35.27 \\
CPS (M/S) & 5.60 & 0.00 & 2.50 & 1.80 & 23.80 & 65.90 \\
DPS (C5) & 5.96 & 0.00 & 2.66 & 2.36 & 18.86 & 151.16 \\
E3 & 4.60 & 0.40 & 1.08 & 0.54 & 2.85 & 15.12 \\
E5 & 4.50 & 0.20 & 0.50 & 0.17 & 1.96 & 5.04 \\
P1Bb & 4.88 & 0.20 & 1.89 & 1.14 & 16.01 & 15.12 \\
P5Bb & 5.30 & 0.10 & 3.06 & 2.07 & 17.20 & 20.16 \\
P15Bb & 4.75 & 0.30 & 1.76 & 1.01 & 13.35 & 15.12 \\
P5Ag & 5.69 & 0.00 & 2.90 & 2.13 & 3.69 & 50.39 \\
ILP & 5.96 & 0.00 & 3.07 & 2.24 & 47.45 & 55.43 \\
Cof 3 & 5.00 & 0.60 & 1.87 & 1.45 & 24.51 & 131.01 \\
Cof 20 & 5.27 & 0.00 & 2.44 & 1.71 & 54.80 & 55.43 \\
\hline
\end{tabular}

$\mathrm{pH}=$ Hydrogen potential; $\mathrm{Ca}^{2+}=$ Calcium; $\mathrm{Mg}^{2+}=$ Magnesium; $\mathrm{Al}^{3+}=$ Aluminum; $\mathrm{K}^{+}=$Potassium; $\mathrm{P}=$ Phosphorus; $\mathrm{C}=$ Carbon.

Granulometry, total organic carbon, soil density, and aggregate stability

Granulometry was determined using the pipette method with sodium hydroxide $(1 \mathrm{~N} \mathrm{NaOH})$ as dispersant. Total organic carbon (TOC) was determined by hot oxidation with potassium dichromate in a sulfuric medium, as recommended by Embrapa (2017). Undisturbed samples, collected in cylinders of known volume and in the form of monoliths, served to determine soil density (SD) according to Embrapa (2017). For determination of aggregates, the samples were passed through 10- and 8-mm sieves, separating the aggregates that were retained in the $8-\mathrm{mm}$ sieve to perform the analyses. A mass of $50 \mathrm{~g}$ of aggregates of the aforementioned size class was transferred to a set of sieves of the Yoder apparatus, being slowly saturated for 10 minutes with the aid of a deionized water atomizer; and a mass of $20 \mathrm{~g}$ was separated for moisture determination according to Embrapa (2017). After saturation, samples on the $2 \mathrm{~mm}$ sieve over 1.000 , $0.500,0.250$, and $0.1060-\mathrm{mm}$ sieves were submerged in a $0.03 \mathrm{~m}$ high water slide and sieved for 15 minutes to separate the aggregate classes. The device used oscillated at the frequency of 30 cycles per minute with a $0.03 \mathrm{~m}$ stroke. After 15 minutes, the aggregates retained in each sieve were transferred to an aluminum capsule with the aid of a jet of water delivered with a pissette. These were taken to an air circulation oven at $105^{\circ} \mathrm{C}$ for $24 \mathrm{~h}$ for later weighing to determine the dry matter of each class of aggregates.

\section{Analyzed variables and statistical procedure}

The variables analyzed were granulometry, total organic carbon (TOC), soil density (SD), percentage of aggregates greater than $2 \mathrm{~mm}(\mathrm{Ag}>2 \mathrm{~mm})$, macroaggregates (MAAG), microaggregates (MIAG), weighted mean diameter (WMD), and geometric mean diameter (GMD). The WMD and GMD were determined according to the equations described in Kemper \& Rosenau (1986):

WMD $=\sum_{i=1}^{n}\left(x_{i} w_{i}\right)$

Wherein: $x_{i}=$ mean diameter of the aggregate classes $(\mathrm{g}) ; w_{i}=$ proportion of each aggregate class in relation to

the total.

Wherein: $\mathrm{wp}=$ mass of the aggregates of each class $(\mathrm{g})$.

\section{Statistical analysis}

The data were subjected to descriptive statistics and analysis of variance, with comparison of means by the Scott-Knott at 5\% probability, using the ASSISTAT software.

\section{Results and discussion}

\section{Granulometry}

Figure 1 shows the distribution of sand, silt, and clay data for the areas under study (histogram and probability density function (PDF)). According to the Shapiro-Wilk test, none of the particle size fractions followed a Gaussian distribution. In addition, only the sand fraction showed negative asymmetry, indicating that sandy soils predominate among the soils under study. On the other hand, silt and clay showed positive asymmetry, determining that most soils have low content of these fractions. 

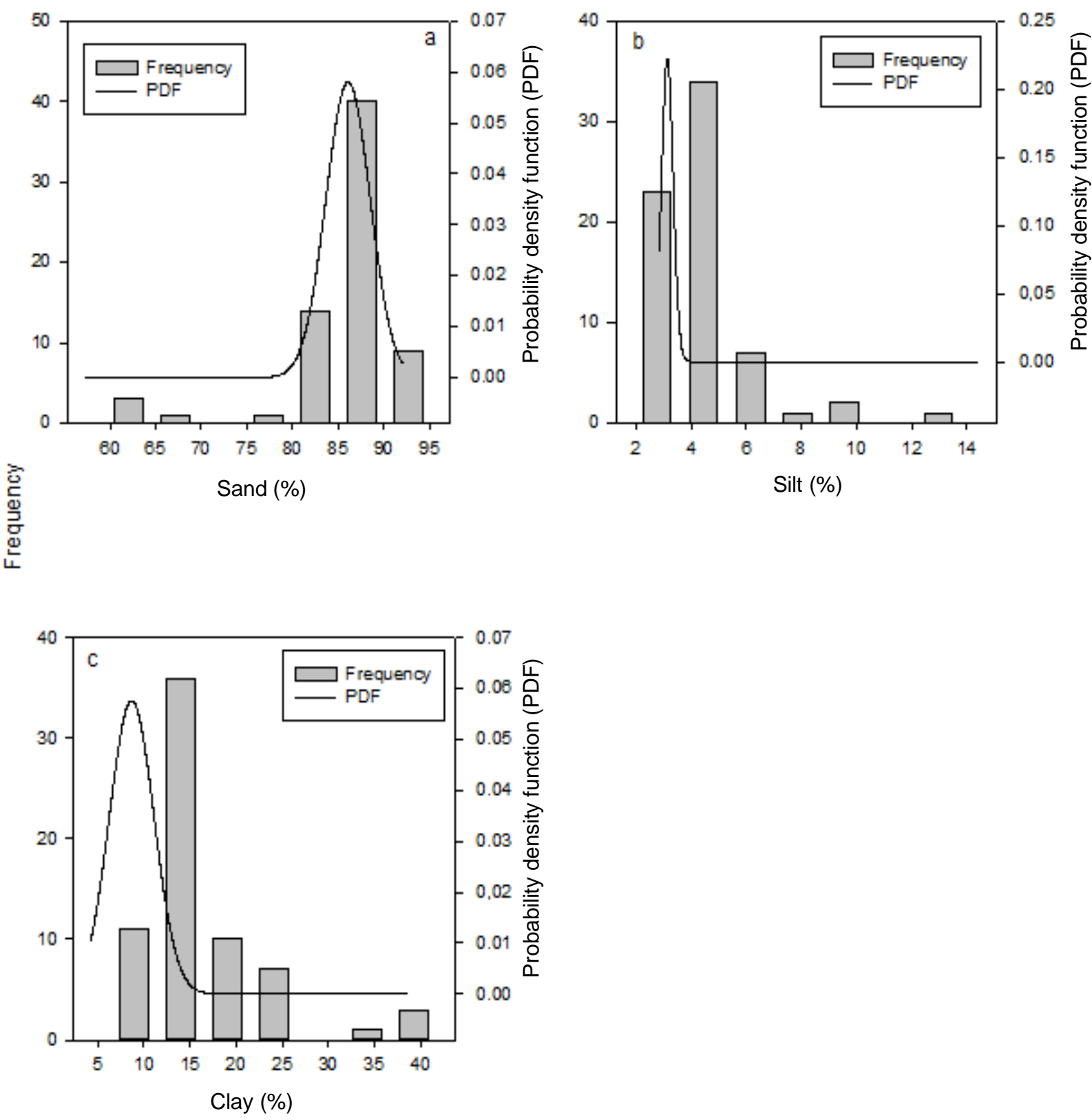

Figure 1 - General distribution of the contents of sand (a), silt (b) and clay (c) of the evaluated soils.

The sand fraction was dominant in the series of soils under study (Table 3), a fact that is justified by the coarse nature of the source material, which originates from sandstones of the Urucuia Formation (Santos et al., 2016). Negative asymmetry indicates that the mean is less than the median, suggesting a higher frequency of values above this parameter. The opposite occurred with the variables silt and clay, in which asymmetry was positive and the mean was greater than the median.

Table 3 also shows that kurtosis values were all positive, indicating leptokurtic curves.
According to the criteria proposed by Warrick \& Nielsen (1980), who classify data variability as low $(\mathrm{CV}<12 \%)$, medium $(12<\mathrm{CV}<60 \%)$, and high (CV $>60 \%)$, the variability of textural attributes ranged between low and medium, in which sand had the lowest value, and silt and clay had the highest values. Therefore, the sand fraction, with CV below $12 \%$, was less heterogeneous in the study area; the other variables, silt and clay, showed a CV above $50 \%$. 
Table 3 - Descriptive statistics of the granulometry of the evaluated soils.

\begin{tabular}{|c|c|c|c|}
\hline \multirow{2}{*}{ Parameter } & Sand & Silt & Clay \\
\hline & \multicolumn{3}{|c|}{-- } \\
\hline Minimum & 56.95 & 1.03 & 3.89 \\
\hline Maximum & 92.16 & 12.79 & 38.76 \\
\hline Average & 82.80 & 3.71 & 13.49 \\
\hline Standard deviation & 6.88 & 1.87 & 6.81 \\
\hline Median & 84.11 & 3.27 & 12.49 \\
\hline Asymmetry & -2.34 & 2.34 & 2.17 \\
\hline Kurtosis & 6.27 & 8.15 & 5.99 \\
\hline Coefficient of variation & 8.31 & 50.41 & 50.44 \\
\hline
\end{tabular}

\section{Total organic carbon (TOC) and soil density (SD)}

Figure 2 shows the frequency distributions of the TOC and SD values, with all data referring to the $0.00-0.20 \mathrm{~m}$ depth. The TOC variable had a normal distribution ( $p=0.1229$ ) according to the Shapiro-Wilk test, with $p<0.05$ (Figure 1a). Santos et al. (2013) found a similar result for various soils in five Brazilian biomes. On the other hand, SD did not present a normal distribution $(p<0.01)$, probably due to the greater sensitivity of soil density to use and management.

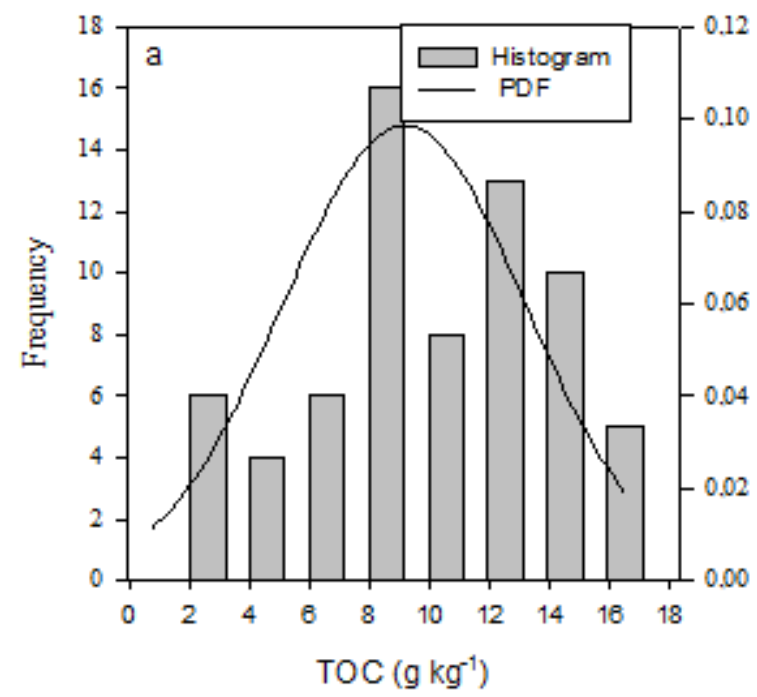

PDF - Probability density funcion

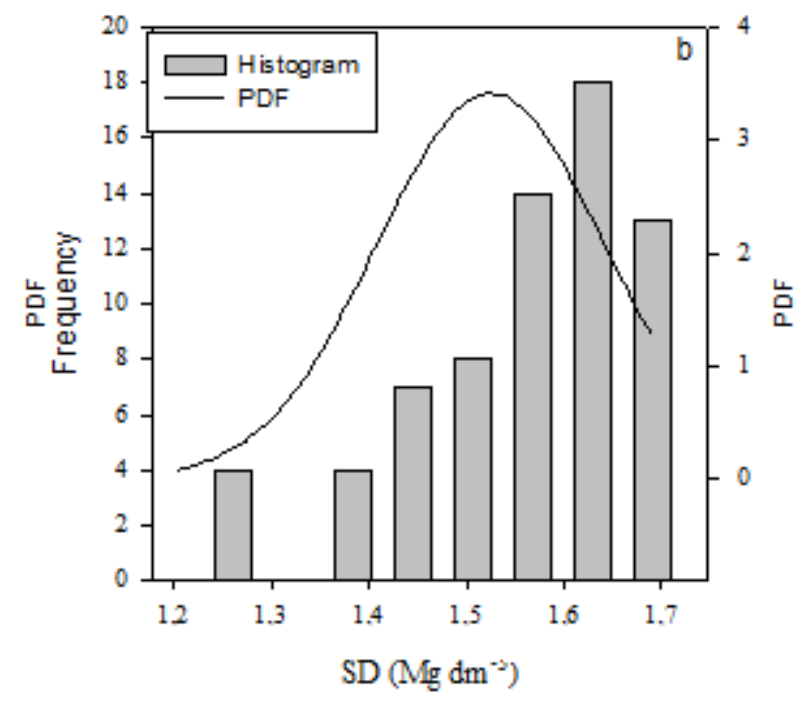

Figure 2 - General distribution of total carbon content (TOC) and soil density (SD).

The distribution of TOC data ranged from 0.58 to $16.51 \mathrm{~g} \mathrm{~kg}^{-1}$, confirming the wide representativeness of the uses/managements used in the database, which is also corroborated by the coefficient of variation (Table
4). Soil density (SD) presented a small amplitude between the maximum and the minimum value of the series, thus having low relative variation.

Table 4 - Descriptive statistics of total organic carbon (TOC) and soil density (SD) in the evaluated areas.

\begin{tabular}{lcc}
\hline Parameter & TOC $\left(\mathrm{g} \mathrm{kg}^{-1}\right)$ & $\mathrm{SD}\left(\mathrm{Mg} \mathrm{m}^{-3}\right)$ \\
\hline Minimum & 0.58 & 1.20 \\
Maximum & 16.51 & 1.69 \\
Average & 9.15 & 1.53 \\
Standar deviation & 4.05 & 0.12 \\
Median & 8.81 & 1.55 \\
Asymmetry & -0.20 & -0.96 \\
Kurtosis & -0.81 & 0.68 \\
\hline Coefficient of variation (\%) & 44.24 & 7.67 \\
\hline
\end{tabular}


Asymmetry demonstrates how far the distribution deviates from the normal curve. Table 4 shows negative values for the two variables (TOC and SD), thus indicating asymmetric distributions on the left. Total organic carbon (TOC) values were close to zero, thus confirming its normality. Soil revolving managements probably skewed the asymmetry to the left due to the low values of TOC (Novelli et al., 2011) and SD. In turn, DPS, ILP, and areas with perennial crops presented higher TOC content (Zhang et al., 2017) and higher SD values. For kurtosis, TOC showed a flatter curve (platykurtic), indicating greater data dispersion, while SD presented itself as a series of data with less dispersion around the mean (leptokurtic curve).

Regarding soil density, the native Cerrado (NC) area had the lowest average, while the CPS (S/M) area had the highest average (Figure 3a). Among the annual crops, DPS (C5) had the lowest average. However, even with the lowest average, the values for this system are considered high due to the clay content (Luciano et al., 2012).
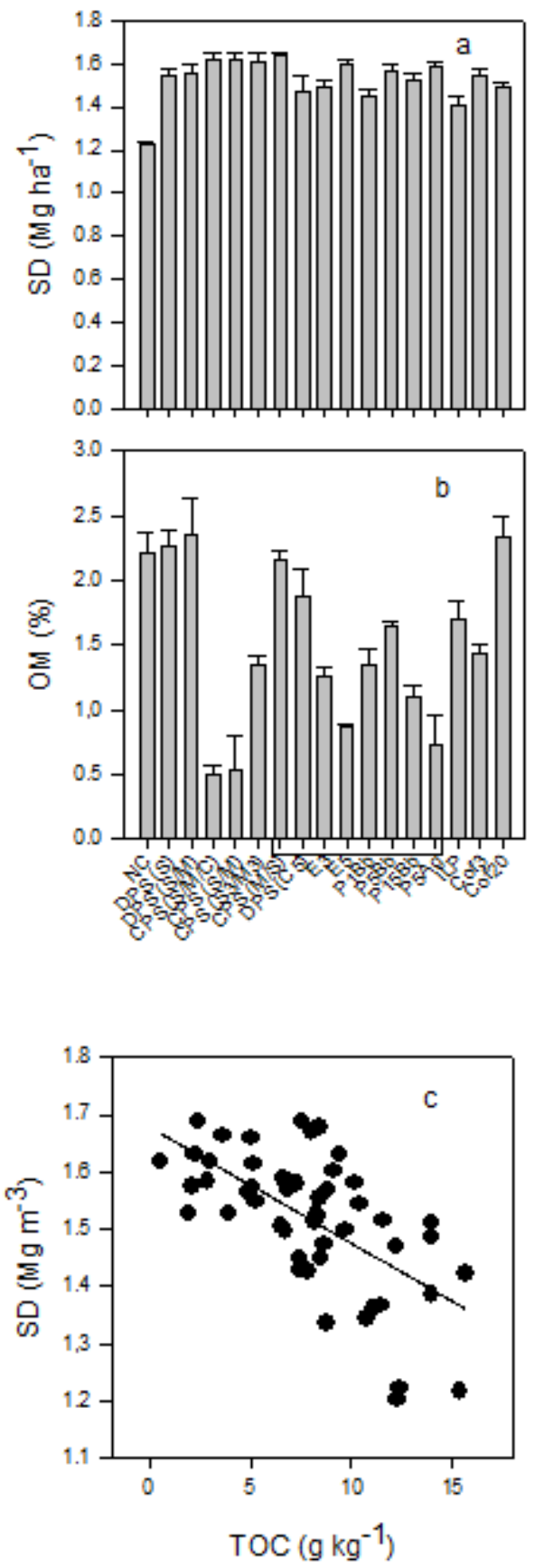

Figure 3 - Soil density (SD)I and organic matter (OM) in relation to use/management and SD as function of total organic carbon (TOC). 
The areas with the lowest organic matter content were CPS $(\mathrm{S} / \mathrm{M} / \mathrm{C})$ and $\mathrm{CPS}(\mathrm{S} / \mathrm{M})$ (Figure $3 \mathrm{~b})$. Novelli et al. (2011) also reported a reduction in organic carbon in soils cultivated with soybean under conventional tillage. However, DPS (S/M), DPS (S), and Cof 20 areas showed organic matter levels similar to those of NC. This fact may be due to the management without soil revolving, since this type of cultivation favors the accumulation of organic matter (Zhang et al., 2017). The area cultivated with cotton (CPS (S/M/C)) showed low organic matter content (Figure $3 b$ ). If one considers the high clay content of this soil, it appears that a high revolving intensity accelerates the decomposition of organic matter, canceling the protection of clay. These results disagree with those of Sollins et al. (1996) and Kučerík et al. (2018), who state that clay and oxides are the main minerals responsible for soil carbon interaction and protection.
The negative correlation between TOC and SD was already expected (Figure 3c). The increase in carbon content decreased soil density in the proportion of $0.0203 \mathrm{Mg} \mathrm{m}^{-3}$ for each g kg${ }^{-1}$ of TOC. Although the $R^{2}$ value was low $(0.40)$, it was similar to that found by Freitas et al. (2018), $R^{2}=0.54$.

For both the weighted mean diameter (WMD) and the geometric mean diameter (GMD), the annual crops were those that obtained the lowest averages, except for DPS (S/M) (Figure 4). This area was cultivated under no-tillage with rotation of soybean and maize, which may have influenced the greater aggregation. Even so, Novelli et al. (2011) found that successive soybean crops, even in different soil classes, reduced organic carbon and aggregation. On the other hand, Nouwakpo et al. (2018) observed that maize cultivation was more efficient in maintaining aggregate stability than soybean cultivation.

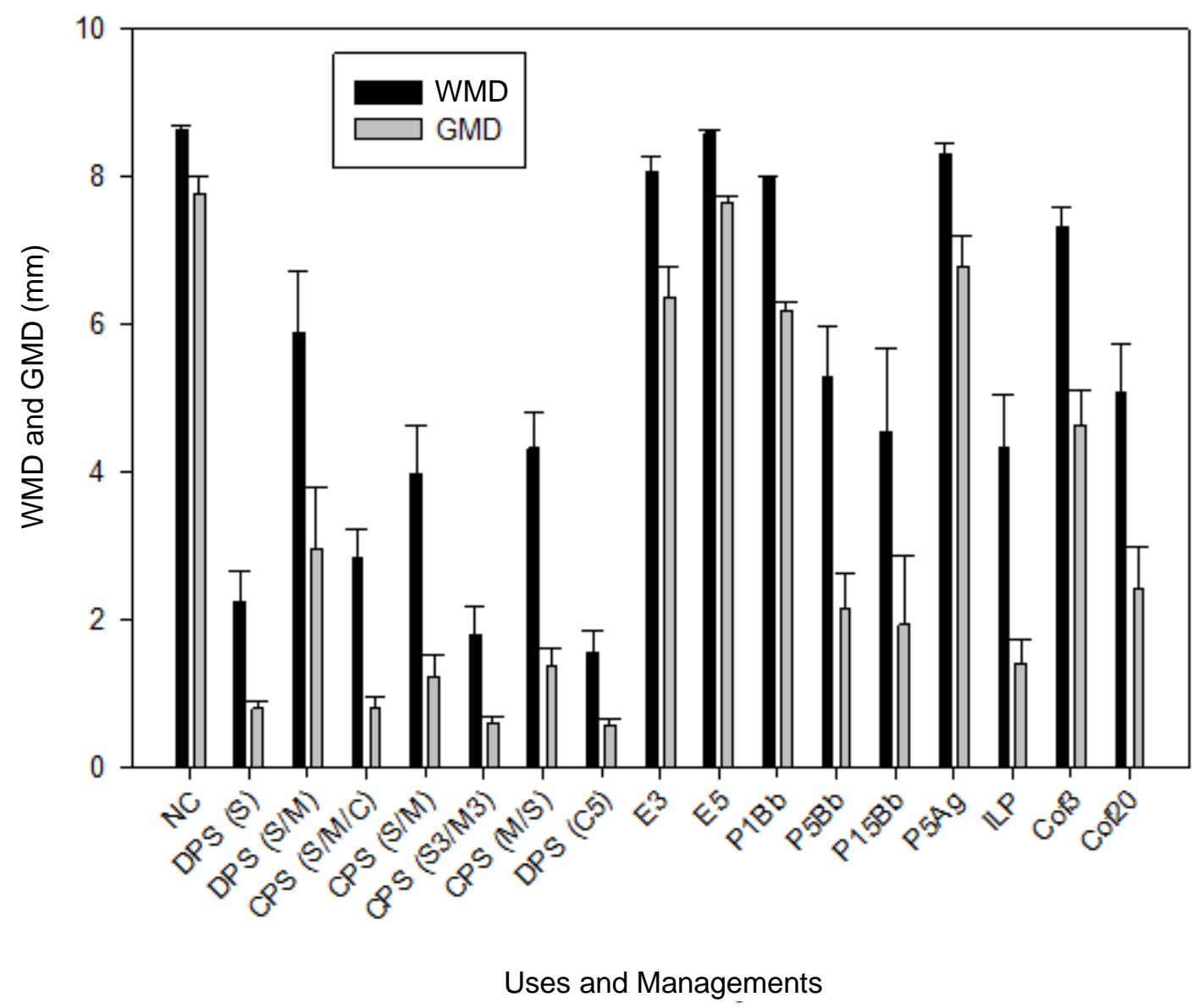

Figure 4 - Weighted mean diameter (WMD) and geometric mean diameter (GMD) of soils as function of use andmanagement according to described in table 1.

The areas cultivated with cotton are among those with the lowest values of WMD and GMD, even though these areas are cultivated under no-tillage systems and have the highest clay contents (Figure 4). The findings disagree with Silva et al. (2014) and Zhang et al. (2017), who state that these factors contribute significantly to soil aggregation. Therefore, it can be inferred that the reduction in aggregation was due to the cultural treatment required by the crop. On the other hand, the clay mineralogy of Oxisols in western Bahia 
consists mainly of kaolinite, which makes these soils highly fragile in terms of structure when handled (Freitas et al., 2014), presenting lower values of water-stable aggregates (Ferreira et al., 1999). In addition, a large amount of pesticides are used in cotton cultivation and these can impact the soil microorganism community (Verdenelli et al., 2012; Kumar et al., 2017). This community is fundamental in the formation and stabilization of aggregates (Rashid et al., 2016). Soil aggregation is influenced by arbuscular mycorrhizal fungi (Zhang et al., 2012) and these can be inhibited not only by phytosanitary products but also by the $\mathrm{Bt}$ technology (Chen et al., 2016) used in cotton crops in the area under study.

The cultivated areas that obtained the highest WMD and GMD values were eucalyptus E1 and E5, pasture $(\mathrm{P} 1 \mathrm{Bb})$ and $(\mathrm{P} 5 \mathrm{Ag})$, and Cof 3 , which did not differ from the native Cerrado area. The greater aggregate stability in the area cultivated with eucalyptus may be due to the hydrophobicity of aggregates correlating with compounds produced by this plant (Ruwanza et al., 2013). When studying different forest covers and pasture, Cunha Neto et al. (2018) observed that the pasture areas were the ones that came closest to the reference native vegetation with regard to aggregate stability.

The WMD and GMD showed a similar trend in the percentage of aggregates larger than $2 \mathrm{~mm}$, with annual crops showing the lowest means in comparison to perennial crops and the native Cerrado vegetation (Figure 5). This class of macroaggregates was more important for detecting differences between the systems than the set of all macroaggregates together (from 0.25 to $>2 \mathrm{~mm}$ ). It can also in Figure 5 that the macroaggregates were not able to differentiate the DPS (S) and DPS (S/M), areas which are different when considering aggregate variables greater than $2 \mathrm{~mm}$.

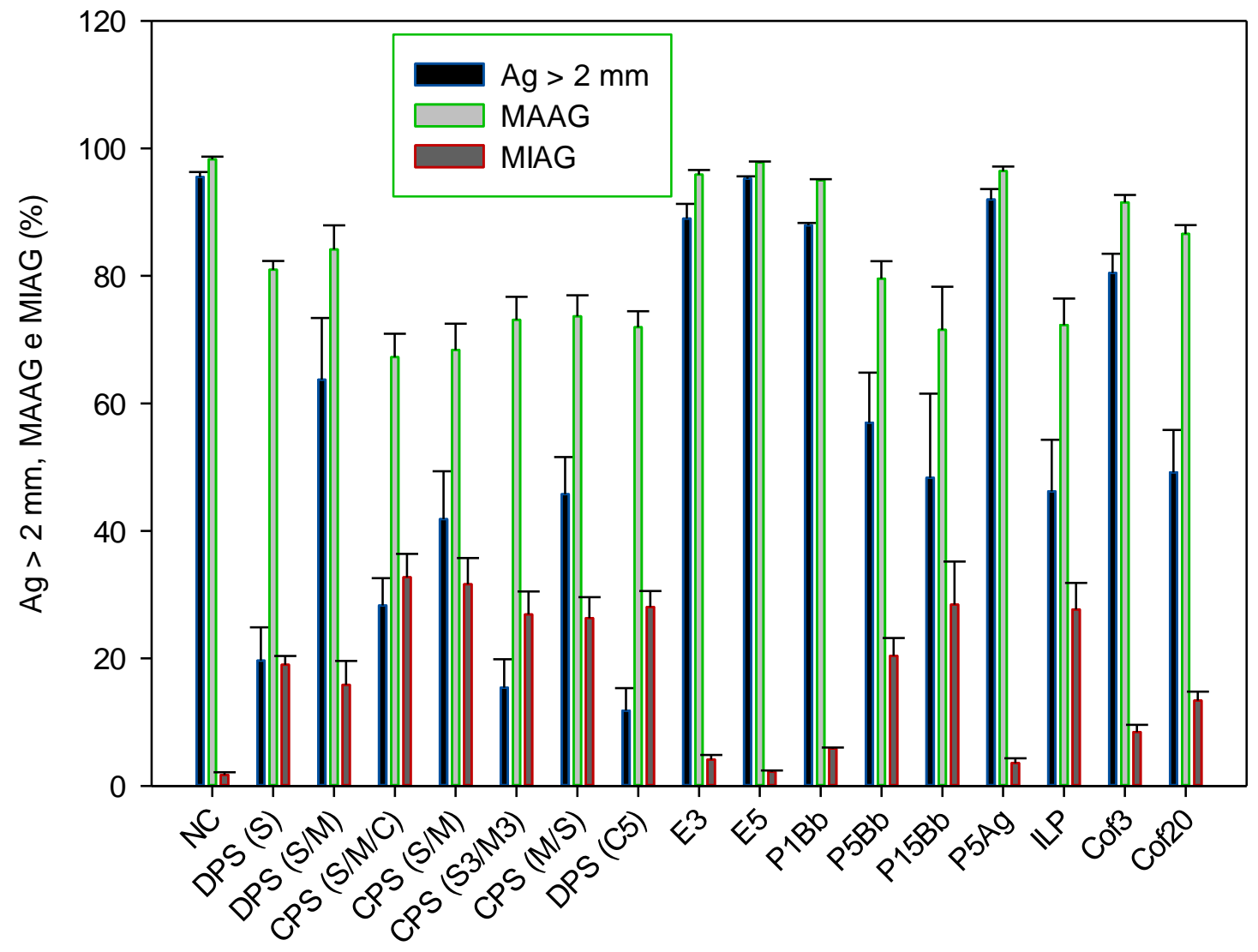

Uses and Managements

Figure 5 - Aggregate $>2 \mathrm{~mm}(\mathrm{Ag}>2 \mathrm{~mm})$, macroaggregates (MAAG) and microaggregates (MIAG) as a function of the type of use and management according to described in table 1.

The areas with the highest percentages of MAAG, WMD, and GMD were those with the lowest percentages of MIAG (Figure 5). Thus, the areas that had the lowest percentage of microaggregates were perennial crops and pasture areas, possibly due to their low agricultural machinery traffic. 


\section{Conclusions}

Total organic carbon was distributed according to the normal curve within the samples under study.

Soil density increased significantly in cultivated areas in comparison to the reference area (NC).

Perennial crops improved soil aggregation in comparison to annual crops.

Cotton cultivation was the one that most affected soil aggregation, even under no-tillage.

For soybean, no-tillage improved soil aggregation in comparison to conventional tillage.

The no-tillage system proved to be efficient in maintaining soil organic matter in soybean growing areas.

\section{References}

AIBA (2018) Associação de Agricultores e Irrigantes da Bahia. Anuário da Região Oeste da Bahia: safra 2017/18, Barreiras, BA. 75p.

Bronick CJ, Lal R. (2005) Soil structure and management: a review. Geoderma 124(1): 3-22.

Chen XH, Wang FL, Zhang R, Ji LL, Yang ZL, Lin H, Zhao B (2016) Evidences of inhibited arbuscular mycorrhizal fungal development and colonization in multiple lines of Bt cotton. Agriculture, Ecosystems and Environment, 230(8): 169-76.

Cunha Neto FV , Pereira MG, Lelis PS dos S, Abel EL da S (2018) Atributos químicos e físicos do solo em áreas sob diferentes coberturas florestais e pastagem em Além Paraíba-MG. Ciência Florestal 28(1):13-24.

Donagemma GK, Freitas PL, Balieiro F de C, Fontana A, Spera ST, Lumbreras JF, Viana JHM, Araújo Filho JC de, Santos FC dos, Albuquerque MR de, Macedo MCM, Teixeira PC, Amaral AJ, Bortolon E, Bortolon L (2016) Characterization, agricultural potential, and perspectives for the management of light soils in Brazil. Pesquisa Agropecuária Brasileira 51(9):1003-1020.

Embrapa (2017) Empresa Brasileira de Pesquisa Agropecuária. Manual de métodos de análise do solo. $3^{\circ}$. ed. Brasília. 574p.

Ferreira MM, Fernandes B, Curi N (1999) Influência da mineralogia da fração argila nas propriedades físicas de latossolos da região Sudeste do Brasil. Revista Brasileira de Ciência do Solo, 23:515-524.

Freitas PL, Polidoro JC, Santos HG, Prado RB, Calderanos SB, Gregoris G, Manzatto CV, Dowich I, Bernardi, ACC (2014) Identificação e caracterização físico-química de latossolos de textura arenosa e média da região oeste da Bahia. Cadernos de Geociências, v. 11(2):83-93.
Freitas L, Oliveira IA, Casagrande JC, Silva LS, Campos MCC (2018) Estoque de carbono de latossolos em sistemas de manejo natural e alterado. Ciência Florestal 28(1):228-239.

Hamza MA, Anderson WK (2005) Soil compaction in cropping systems: A review of the nature, causes and possible solutions. Soil and Tillage Research 82(2): 121-145.

Kemper DW, Rosenau RC (1986) Aggregate stability and aggregate size distribution. In: Klute A (ed.) Methods of soil analysis, Department of Agriculture, Agricultural Research Service, cap. 17, p. 425- 442.

Kučerík J, Tokarski D, Demyan MS, Merbach I, Siewert C (2018) Linking soil organic matter thermal stability with contents of clay, bound water, organic carbon and nitrogen. Geoderma, 316(4): 38-46.

Kumar U, Berliner J, Adak T, Rath PC, Dey A, Pokhare SS, Jambhulkar NN, Panneerselvam P, Kumar A, Mohapatra SD (2017) Non-target effect of continuous application of chlorpyrifos on soil microbes, nematodes and its persistence under sub-humid tropical rice-rice cropping system. Ecotoxicology and Environmental Safety 135: 225-235.

Luciano RV, Albuquerque JA, Costa A, Batistella B, Warmling MT (2012) Atributos físicos relacionados à compactação de solos sob vegetação nativa em região de altitude no sul do Brasil. Revista Brasileira de Ciência do Solo 36(6):1733-1744.

Nouwakpo SK, Gonzalez JM, Song J (2018) Soil structural stability assessment with the fluidized bed, aggregate stability, and rainfall simulation on long-term tillage and crop rotation systems. Soil and Tillage Research 178:65-71.

Novelli LE, Melchiori R, Caviglia O (2011) Impact of soybean cropping frequency on soil carbon storage in Mollisols and Vertisols. Geoderma167:254-260.

Obade VP, Lal R (2016) Towards a standard technique for soil quality assessment. Geoderma 265:96-102.

Rashid MI, Mujawar LH, Shahzad T, Almeelbi T, Ismail IMI, Oves M (2016) Bacteria and fungi can contribute to nutrients bioavailability and aggregate formation in degraded soils. Microbiological Research 183:26-41.

Ruwanza, S Richardson M, Esler DM, Karen J (2013) Soil water repellency in riparian systems invaded by Eucalyptus camaldulensis: a restoration perspective from the Western Cape Province, South Africa. Geoderma 200:9-17. 
Santos GB, Oliveira CHP, Cruz D dos S, Pinto Júnior L de L, Silva TS (2016) Gleissolo em ambiente de vereda no chapadão do urucuia, oeste da Bahia Geographia Meridionalis 4(1):44-56.

Shi P, Schulin R (2018) Erosion-induced losses of carbon, nitrogen, phosphorus and heavy metals from agricultural soils of contrasting organic matter management. Science of the Total Environment 618: 210-218.

Silva AS, Silva I de F, Bandeira LB, Dias B de O, Silva Neto L de $F$ (2014), Argila e matéria orgânica e seus efeitos na agregação em diferentes usos do solo. Ciência Rural 44(10) 2014.

Sollins P, Homann P, Caldwell BA (1996) Stabilization and destabilization of soil organic matter: mechanisms and controls. Geoderma 74(1): 65-105.
Verdenelli RA, Lamarque AL, Meriles JM (2012) Shortterm effects of combined iprodione and vermicompost applications on soil microbial community structure. Science of the Total Environment 414: 210-219.

Zhang S, Zhang XP, Li Q, Wei K (2012) Effects of conservation tillage on soil aggregation and aggregate binding agents in black soil of Northeast China. Soil and Tillage Research 124:196-202.

Zhang X, Xin X, Zhu A, Zhang J, Yang W (2017) Effects of tillage and residue managements on organic $C$ accumulation and soil aggregation in a sandy loam soil of the North China Plain. Catena 156:176-183.

Warrick AW, Nielsen DR (1980) Spatial variability of soil physical properties in the field. In: Hillel D, (ed.) Application of soil physics. New York: Academic Press, cap. 2, p. 319 - 324. 